Reply

\title{
Reply to Sinha, P.; Wade, A. Comment on "Nover et al. Leaching via Weak Spots in Photovoltaic Modules. Energies 2021, 14, 692"
}

\author{
Juergen Heinz Werner ${ }^{1,}{ }^{*}$, Renate Zapf-Gottwick ${ }^{1}$, Jessica Nover ${ }^{1}$ and Michael Koch ${ }^{2}$ (D) \\ 1 Institute for Photovoltaics and Research Center SCoPE, University of Stuttgart, 70569 Stuttgart, Germany; \\ renate.zapf-gottwick@ipv.uni-stuttgart.de (R.Z.-G.); jessica.nover@ipv.uni-stuttgart.de (J.N.) \\ 2 Institute for Sanitary Engineering, Water Quality, and Solid Waste Management, University of Stuttgart, \\ 70569 Stuttgart, Germany; Michael.Koch@iswa.uni-stuttgart.de \\ * Correspondence: juergen.werner@ipv.uni-stuttgart.de
}

check for updates

Citation: Werner, J.H.;

Zapf-Gottwick, R.; Nover, J.; Koch, M. Reply to Sinha, P.; Wade, A. Comment on "Nover et al. Leaching via Weak Spots in Photovoltaic Modules. Energies 2021, 14, 692". Energies 2021, 14, 3208. https:// doi.org/10.3390/en14113208

Received: 12 April 2021

Accepted: 25 May 2021

Published: 31 May 2021

Publisher's Note: MDPI stays neutral with regard to jurisdictional claims in published maps and institutional affiliations.

Copyright: (c) 2021 by the authors. Licensee MDPI, Basel, Switzerland. This article is an open access article distributed under the terms and conditions of the Creative Commons Attribution (CC BY) license (https:/ / creativecommons.org/licenses/by/ $4.0 /)$.

\section{Introduction}

In their comment [1], Sinha and Wade made several remarks on our long-term leaching studies [2] of photovoltaic (PV) modules. Both authors work for the company First Solar, whose main product is CdTe modules. Similar to previous publications [3-5], we again found CdTe not to be stable in aqueous solutions, not even in neutral water with $\mathrm{pH} 7$ [2]. Thus, it is not a question anymore if the carcinogenic $\mathrm{Cd}$ and Te are leached out from CdTe module pieces but just a question of how long it takes.

Sinha and Wade [1] described well-known standard module testing methods at length. Those methods are type tests, which are applied to a relatively small number of modules for each module type before distribution; they must not be mixed up with routine tests of individual modules of the same type before distribution. In contrast, our data are relevant for distributed, installed, individual, damaged modules in the field, or for those which, after end of use, may end up in landfills.

Indeed, our research and publications [2-5] have been followed and persecuted [6] by Sinha and Wade during the last few years, similarly to research of others [7-9]. We replied on their comments already earlier [10]. Here, Sinha and Wade essentially use the following arguments, to seed doubts against our leaching studies [1]:

(i) Our leaching experiments, which varied $\mathrm{pH}$, time, temperature, and encapsulation would be "artificial and do not occur in nature".

(ii) Using buffered solutions (to keep the $\mathrm{pH}$ constant over the time of the experiments) for leaching experiments would not represent "actual field conditions".

(iii) Acidic solutions with $\mathrm{pH} 3$ would neither be representative for leaching in rainwater nor for landfills.

(iv) An earlier study of Steinberger [11] using rainwater found leachate concentrations to "meet environmental limits".

(v) "With respect to end-of-life landfill disposal, recent research from Nain and $\mathrm{Ku}$ mar [12] shows that standard short-term waste characterization tests overestimate leaching risks from PV modules, in comparison to observed long-term (60-day) leaching using actual landfill leachate."

\section{Our Replies}

\subsection{Variation of $\mathrm{pH}$, Time, Temperature, Agitation}

Indeed, our conditions are artificial; in nature, they are probably even worse. For example, in a landfill, module pieces might be subjected (even simultaneously) to inorganic and organic liquids, microbes (bacteria, archaea, fungi), insects, electrocorrosion due to illumination, and so on. To keep conditions well-defined and simple, we restricted our studies to time-dependent leaching in water-based solutions with $\mathrm{pH} 3, \mathrm{pH} 7$, and $\mathrm{pH} 11$ in the dark [2]. Indeed, our carefully designed experiments showed the leaching to depend not 
only on $\mathrm{pH}$ but also on temperature and agitation, and in case of CdTe modules [2] also on the size and shape of CdTe particles [5]. The wide range of $\mathrm{pH}$ values allows one now to predict the behavior of module pieces subjected to water-based solutions with other pH-values, see also Ref. [10].

\subsection{Constant $p H$ by Buffering}

Identification of leaching mechanisms, time dependences, and measuring the leaching speeds over a long period in time $t$ (up to $t \approx 1.5$ years) requires keeping the $\mathrm{pH}$ constant (as well as temperature, lack of illumination, possible agitation, etc.), despite leaching out not only the toxic substances but also dissolving the module glass. This glass dissolution leads to a slow increase of the $\mathrm{pH}$ if the volume of the solution is constant. For example, such an increase is shown in Figure 1 of Ref. [1]. The speed of the $\mathrm{pH}$ increase depends on the ratio of the volume of module pieces to the volume of the leaching solvent. Unfortunately, Sinha and Wade [1] did not give information about this ratio. In addition, the contact of the solutions to ambient air (also not mentioned by Sinha and Wade [1]) could also increase the $\mathrm{pH}$ of the solutions. Thus, a $\mathrm{pH}$ increase with time is possible even without module pieces if the volume of the solution is limited. This matter could be clarified by a proper reference experiment! To come up with conclusive leaching data for module pieces in a water-based leaching solution of well-defined $\mathrm{pH}$, we decided to use buffered solutions with a limited volume of about 1 liter. The bottles were closed and lightproof. The buffering itself only keeps the $\mathrm{pH}$ constant over time; it does not change the leaching, but buffering allows one to find the $\mathrm{pH}$ dependence of the leaching speed, i.e., the dependence of the leached amount for each element on time $t$ ! Alternatively, to keep the $\mathrm{pH}$ constant over time $t$ via buffering, we could have used (and wasted) huge amounts of solutions in huge tanks and added the small module pieces. With the known leaching speeds for different $\mathrm{pH}$ values, we are now able to model leaching also for a time-dependent $\mathrm{pH}(t)$. Nevertheless, even in nature, the $\mathrm{pH}$ of the "solution" might also be constant in time, simply because, for example, rainwater flows over the module pieces, leaches out the toxic substances, and then drains away. With the next rain, new rainwater with similar $\mathrm{pH}$ may fall, leach again, drain away, and so on. Therefore, the leaching will also never stop.

\subsection{Rainwater and $p H 3 ; p H$ and Landfills}

We used experiments with $\mathrm{pH} 3$ (apart from $\mathrm{pH}$ 7, $\mathrm{pH}$ 11) to have data also on the lower scale of $\mathrm{pH}$ values. This wide range of $\mathrm{pH}$ allows us also to conclude on the action of rainwater, whatever the $\mathrm{pH}$ may be. In Ref. [5] we stated that in Brazil, the $\mathrm{pH}$ of rainwater ranges at $4.2<\mathrm{pH}<6.1$, rainwater in Germany ranges at $4.1<\mathrm{pH}<5.3$, mineralized water ranges at $4.9<\mathrm{pH}<8.4$, and sea water is in the narrow range $7.5<\mathrm{pH}<8.5$. In Figure 1 of their own comment [1], Sinha and Wade hold up against us a $\mathrm{pH} \approx 5.4$ as a median value of average $\mathrm{pH}$ of rainfall for measurement stations in Germany and USA. However, as their value is a median (and not an average value), it means that $50 \%$ of the data point collected by them showed a lower $\mathrm{pH}$ value. Here, not a median, but a mean value would be more informative. In addition, we do not understand why they mixed values of Germany and the USA. Anyway, their own claimed pH data for rainwater fit well into the data quoted by us.

Concerning landfills: We stated earlier in Ref. [5], landfills in Germany to range at $3.4<\mathrm{pH}<11.9$ [Ref. [24] in [5]]. Here, we give again some more detailed, newer data for Germany: The updated Ref. [13] lists measured data for landfills: $3.8<\mathrm{pH}<13.1$ for inorganic waste (page 25 in Ref. [13]), $7.2<\mathrm{pH}<8.3$ for municipal waste (page 12 in Ref. [13]), $2.3<\mathrm{pH}<13.9$ for waste from the building/construction sector (page 30 in Ref. [13]), and $3.3<\mathrm{pH}<12$ for hazardous waste (page 6 in Ref. [13]). For the United Kingdom, we found, for example, $6.2<\mathrm{pH}<8$ [14], and for Malaysia, $4.5<\mathrm{pH}<9$ [15]. Thus, our investigations with $\mathrm{pH} 3, \mathrm{pH} 7$, and $\mathrm{pH} 11$ cover the $\mathrm{pH}$ range of landfills quite well. 


\subsection{Rainwater Studies of Steinberger}

The modules we tested stem from present-day mass production. For the CdTe modules, we observed substantial Cd leaching even for $\mathrm{pH}$ 7: After 1.5 years, about $4.5 \%$ of the $\mathrm{Cd}$ was leached out from the module pieces, even in a limited solution of 1 liter which went into saturation; see Figure $12 \mathrm{~d}$ of Ref. [2]. The cells' Mo back contact is the weak spot [2]. For the quoted pH 5.4 for rainwater of Figure 1 from Sinha and Wade [1], one might expect around $50 \%$ of $\mathrm{Cd}$ to be leached out during the same time- simply due to the higher $\mathrm{Cd}$ solubility limit for the lower $\mathrm{pH}$. In contrast, Steinberger's publication from 1998 [11] reported low Cd leaching for his experiments with rainwater; the source of the CdTe modules was not revealed. Only one module stemmed from commercial production-we guess from the early CdTe production of the German company Antec Solar. Unfortunately, the type, the quality, and the deposition method of the back contact, as well as the quality of sealing of these modules is not known to us. Such differences may or may not be the reason for the possibly different leaching behavior-if it exists at all! The experimental conditions of Steinberger's early, rather short publication [11] were only poorly described, as already stated by us in our reply [10] to Ref. [6]. Only the size of the module pieces $(10 \mathrm{~mm})$ was mentioned in Ref. [11]. Nothing was stated about their shape, their sealing, the $\mathrm{pH}$, the redox potential, the temperature, and the total amount of water in which the module pieces were immersed. Did he measure the leached-out amount per week, or the total amount? In addition, what analysis method for the Cd was used and after which time? Did he measure the $\mathrm{Cd}$ in the solution or the $\mathrm{Cd}$ in precipitates? For low $\mathrm{pH}$, we did not find precipitation: all $\mathrm{Cd}$ was in the solution [2]. We also cannot exclude an influence of illumination in his [11] experiments. Thus, only a proper repetition of Steinberger's experiments [11] under well-defined conditions with well-defined samples might be convincing.

\subsection{Leaching Studies of Nain and Kumar}

The statement of Nain and Kumar [12] as quoted above, in our opinion, means that standard short-term waste characterization tests (for example over 6 or $24 \mathrm{~h}$ ) are inappropriate to judge the long-term leaching risks from PV modules under field conditions or if they stay forever in landfills. We would agree with this interpretation. Nain and Kumar [12] did not study any CdTe modules. Therefore, no direct conclusions on CdTe modules can be drawn from their interesting experiments. However, they studied $\mathrm{Cd}$ containing CIGS modules and wrote in their abstract: "The leached metal concentrations were found to be within the threshold limits except for cadmium, copper, lead and selenium ...". In addition, "CIGS was found to be most hazardous with a Metal Hazard Score (calculated on the basis of magnitude of leached metals with respect to their threshold limit and subsequent health effects) of 23.19, when exposed to standard tests." Would the hazard not even be higher for CdTe? In case of CIGS cells, the thickness of the CdS buffer layer is only around $40 \mathrm{~nm}$. In case of CdTe/CdS cells, the thickness of the layers is around $4 \mu \mathrm{m}$. Thus, CdTe modules contain about a factor of 100 more carcinogenic $\mathrm{Cd}$ than CIGS-modules. The conclusion of Ref. [12] states $\mathrm{pH} 7.5$ to $\mathrm{pH} 7.8$ for the leaching solutions used. Unfortunately, no value for the redox potentials was given. Clearly, in case of these almost neutral $\mathrm{pH}$ values, the leaching is slow. In addition, clearly over 60 days, the amount of leached out elements is low. After this time (and pH 7) and for a solution with limited volume of 1 liter, we found only about $2 \%$ of the module's $\mathrm{Cd}$ in the solution; see Figure 12d of Ref. [2]. In this respect, the study of Nain and Kumar [12] nicely fits into our data [2] and vice versa. However, in a landfill, the volume of the liquid in most cases will not be finite! Always, new rainwater will come! Then, the solubility limit in the water will not be reached. A saturation behavior as observed by us, see Figure 12a-f in Ref. [2], most probably will not occur, but the leaching will continue. Nain and Kumar stopped their experiments after 60 days. In contrast, photovoltaic module (pieces) in landfills will stay there forever. For low $\mathrm{pH}$, they will be leached out fast; for high $\mathrm{pH}$, the leaching is slow. Thus, in one case, it may take weeks, while in other cases, it may take decades. In 
any case, toxic, hazardous, and carcinogenic substances will be leached out. Only omission of them avoids this process.

Conflicts of Interest: The authors declare no conflict of interest. The funders had no role in the design of the study; in the collection, analyses, or interpretation of data; in the writing of the manuscript, or in the decision to publish the results.

\section{References}

1. Sinha, P.; Wade, A. Comment on Nover et al. Leaching via Weak Spots in Photovoltaic Modules. Energies 2021, 14, 692. Energies 2021, 14, 3150. [CrossRef]

2. Nover, J.; Zapf-Gottwick, R.; Feifel, C.; Koch, M.; Werner, J.H. Leaching via Weak Spots in Photovoltaic Modules. Energies 2021, 14, 692. [CrossRef]

3. Nover, J.; Zapf-Gottwick, R.; Feifel, C.; Koch, M.; Metzger, J.; Werner, J.H. Long-term Leaching of Photovoltaic Modules. Jpn. J. Appl. Phys. 2017, 56, 08MD02. [CrossRef]

4. Zapf-Gottwick, R.; Koch, M.; Fischer, K.; Schwerdt, F.; Hamann, L.; Kranert, M.; Metzger, J.; Werner, J.H. Leaching Hazardous Substances out of Photovoltaic Modules. Int. J. Adv. Appl. Phys. Res. 2015, 2, 7. [CrossRef]

5. Zapf-Gottwick, R.; Zorn, M.; Nover, J.; Koch, M.; Feifel, C.; Werner, J.H. Size- and Surface Dependent Solubility of Cadmium Telluride in Aqueous Solutions. Energies 2021, 14, 398. [CrossRef]

6. Sinha, P.; Wade, A. Comment on “Long-term Leaching of Photovoltaic Modules". Jpn. J. Appl. Phys. 2018, 57, 019101. [CrossRef]

7. Zeng, C.; Ramos-Ruiz, A.; Field, J.A.; Sierra-Alvarez, R. Cadmium Telluride (CdTe) and Cadmium Selenide (CdSe) Leaching Behavior and Surface Chemistry in Response to $\mathrm{pH}$ and $\mathrm{O}_{2}$. J. Environ. Manag. 2015, 154, 78. [CrossRef] [PubMed]

8. Sinha, P. Cadmium Telluride Leaching behavior: Discussion of Zeng et al. (2015). J. Environ. Manag. 2015, 163, 184. [CrossRef] [PubMed]

9. Zeng, C.; Ramos-Ruiz, A.; Field, J.A.; Sierra-Alvarez, R. Response to the Comments on “Cadmium Telluride Leaching Behavior: Discussion of Zeng et al. (2015)". J. Environ. Manag. 2015, 164, 65. [CrossRef] [PubMed]

10. Nover, J.; Zapf-Gottwick, R.; Feifel, C.; Koch, M.; Metzger, J.; Werner, J.H. Reply to “Comment on 'Long-term Leaching of Photovoltaic Modules"”. Jpn. J. Appl. Phys. 2018, 57, 019102. [CrossRef]

11. Steinberger, H. Health, Safety and Environmental Risks from the Operation of CdTe and CIS Thin-Film Modules. Prog. Photovolt. Res. Appl. 1998, 6, 99-103. [CrossRef]

12. Nain, P.; Kumar, A. Understanding Metal Dissolution from Solar Photovoltaics in MSW Leachate under Standard Waste Characterization Conditions for Informing End-of-life Photovoltaic Waste Management. Waste Manag. 2021, 123, 97-110. [CrossRef] [PubMed]

13. Landesamt für Natur, Umwelt und Verbraucherschutz Nordrhein-Westfalen (Lanuv). Fachbericht 24, Beschaffenheit von Deponiesickerwässer 2018. Available online: https://www.lanuv.nrw.de/fileadmin/lanuvpubl/3_fachberichte/30024.pdf (accessed on 11 March 2021).

14. Available online: https://leachate.co.uk/main/leachate-chemistry-testing/landfill-leachate-composition/ (accessed on 11 March 2021).

15. Umar, M.; Hamidi, A.A.; Yusoff, M.S. Variability of Parameters in Leachate Pollution Index and Determination of LPI from Four Landfills in Malysia. Int. J. Chem. Eng. 2010, 2010, 747953. [CrossRef] 